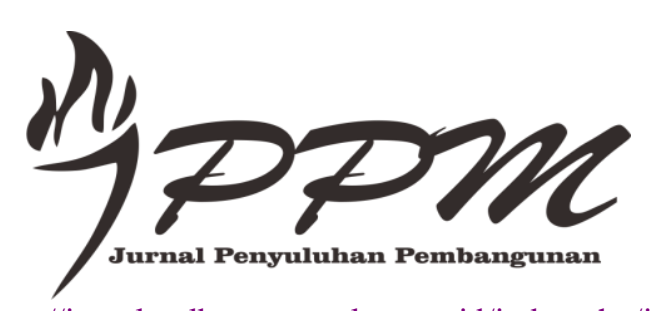

http://jurnal.polbangtanmalang.ac.id/index.php/jppm

Jurnal Penyuluhan Pembangunan Volume 1, Nomor 1 Tahun 2019

\title{
PERAN PEREMPUAN DALAM IMPLEMENTASI PROGRAM KAWASAN RUMAH PANGAN LESTARI
}

\section{THE ROLE OF WOMEN IN THE IMPLEMENTATION OF SUSTAINABLE FOOD HOUSE AREA PROGRAMS}

\author{
Ahmad Dedy Syathori \\ Balai Besar Pelatihan Pertanian Ketindan \\ Jalan Ketindan No 1 Lawang Malang 65215, Tlp/Fax: (0341) 426235/429725 \\ e-mail: ahmaddedy@pertanian.go.id
}

\begin{abstract}
Abstrak
Salah satu yang mendasari dilaksanakannya kegiatan pelaksanaan program pengembagan kawasan rumah pangan lestari adalah belum termanfaatkanya lahan pekarangan yang dimiliki oleh masyarakat secara optimal untuk kegiatan pertanian. Tujuan penelitian ini adalah untuk menganalisis peran dan tingkat partisipasi perempuan dalam implementasi program kawasan rumah pangan lestari. Penelitian ini dilaksanakan bulan Januari sampai dengan Maret 2018 di Kota Malang Provinsi Jawa Timur. Metode pendekatan penelitian yang digunakan dalam penelitian ini adalah metode pendekatan penelitian kualitatif yang bersifat deskriptif dengan menggunakan model analisis Harvard dan analisis Longwee. Hasil penelitian menunjukan bahwa berdasarkan analisis Harvard diketahui bahwa profil aktifitas kaum perempuan dibandingan dengan laki-laki adalah lebih dominan. Pada kegiatan penggunaan teknologi dan pengambilan keputusan terkait budidaya mayoritas dilakukan oleh laki-laki. Pada analisis Longwe bahwa perempuan dijadikan sebagai sasaran program yang pada akhirnya perempuan tidak pernah menjadi sejajar dengan laki-laki dalam pembangunan. Rekomendasi dalam penelitian ini adalah Dinas Pertanian dan Ketahanan Pangan Kota Malang sudah seharusnya peka terhadap fenomena dilapangan, sehingga bisa merumuskan teknologi pertanian dan mampu memformulasikan sebuah teknologi pertanian yang ramah lingkungan.
\end{abstract}

Kata kunci : Peran perempuan, pemanfaatan lahan, pengembangan kawasan rumah pangan lestari. 


\begin{abstract}
One of the reasons for carrying out the implementation of a sustainable food house area development program is that it has not been optimally utilized by the community's land for agricultural activities. The purpose of this study was to analyze the role and level of women's participation in the implementation of sustainable food house area programs. This research was conducted from January to March 2018 in Malang City, East Java Province. The research approach method used in this study is a descriptive qualitative research approach using the Harvard analysis model and Longwee's analysis. The results showed that based on the Harvard analysis it was known that the profile of women's activities compared to men was more dominant. In technology use activities and majority decision making related to cultivation is carried out by men. In Longwe's analysis that women were made as program targets, in the end women never became equal to men in development. The recommendations in this study are that the Department of Agriculture and Food Security of the City of Malang should be sensitive to the phenomena in the field, so that they can formulate agricultural technology and be able to formulate an environmentally friendly agricultural technology.
\end{abstract}

Keyword: The role of women, land use, development of sustainable food house areas.

\title{
I. PENDAHULUAN
}

UU No.6 Tahun 2014 tentang Desa, merupakan peraturan penting yang berdampak pada berbagai aspek kehidupan, termasuk terkait dengan hak, kesejahteraan perempuan dan anak. Sistem patriarki masih berlaku yang mengakibatkan keterlibatan perempuan dalam pengambilan keputusan masih sangat minim, sehingga untuk memberdayakan perempuan sangat penting agar perempuan lebih percaya diri, mampu merumuskan dan menyampaikan permasalahan kepada masyarakat secara efisien. Organisasi/kelompok yang terbentuk dari para perempuan didorong untuk menumbuhkan perekonomian mikro dan lembaga-lembaga desa, seperti usaha mikro kecil dan menengah (UMKM), sehingga dapat meningkatkan taraf hidup masyarakat menjadi lebih berkualitas.

Perempuan berdasarkan penjelasan diatas, terlihat menjadi objek penting dalam pelaksanaan program kawasan rumah pangan lestari (KRPL). Berbagai peraturan yang menjadi dasar pelaksanaan KRPL mulai dari Peraturan Presiden Nomor 22 Tahun 2009 hingga Peraturan Waliota Malang tentang Kebijakan Percepatan Penganekaragaman Konsumsi Pangan Berbasis Sumber Daya Lokal Kota Malang semakin mempertegas posisi perempuan dalam kegiatan ini. Perempuan dalam berbagai peraturan yang ada menjadi sasaran utama dalam KRPL. Model pemberdayaan perempuan dalam pemenuhan kebutuhan pangan keluarga berpotensi mengalami bias gender. Secara ekstrinsik dari peraturan tersebut diatas, terlihat bahwa perempuan dianggap paling bertanggungjawab dan memegang peranan penting dalam pemenuhan pangan keluarga.

Permasalahan dalam KRPL menjadi menarik untuk dibahas mengingat dalam pelaksanaannya menggunakan pemberdayaan perempuan. Kontradiksi terjadi ketika pemberdayaan yang sedianya dapat membebaskan perempuan dari belenggu patriarki malah secara tidak langsung melanggengkan hegemoni patriarki terhadap perempuan. 
Fokus penelitian ini berusaha menguraikan bagaimana budaya patriarki bekerja dengan balutan pemberdayaan perempuan dalam KRPL untuk melanggengkan hegemoninya melalui domestikasi. Semangat pemberdayaan yang diusung dalam KRPL dengan demikian diharapkan benar-benar dapat memberdayakan perempuan, bukan malah sebaliknya melanggengkan hegemoni patriarki, sehingga manfaat KRPL benar-benar dapat dirasakan oleh perempuan.

Penelitian tentang pemberdayaan perempuan dianggap penting, yaitu dengan perempuan mengambil peran dalam program pemberdayaan untuk memanfaatkan peran sosial yang dimilikinya. Pada dasarnya perempuan memiliki peran dalam rumah tangga yang terimplikasi dari: (1) peran produksi dan domestik sebagai ibu rumah tangga, (2) peran sosial sebagai makhluk sosial yang butuh berinteraksi dengan lingkungannya dan sebagai pencari nafkah (tambahan). Akibat meningkatnya pendapatan yang diperoleh melalui pola nafkah tambahan sebagai konsekuensi peran perempuan, maka kebutuhan pangan rumah tangga sehari-hari diharapkan dapat terpenuhi sehingga dapat meningkatkan taraf hidup keluarga.

Pelaksanaan kegiatan program KPRL di Kota Malang dimulai sejak tahun 2012 sampai 2018, salah satu yang mendasari dilaksanakannya kegiatan pelaksanaan program KRPL adalah belum termanfaatkanya lahan pekarangan yang dimiliki oleh masyarakat secara optimal untuk kegiatan pertanian. Sesuai dengan data dari Badan Pusat Statistik bahwa lahan pekarangan yang dimiliki oleh masyarakat Kota Malang seluas 6.837 ha, dengan adanya kegiatan pelaksanaan program kawasan rumah pangan lestari makan lahan-lahan tersebut sudah $27,15 \%$ atau 1.856 ha sudah termanfaatkan untuk kegiatan usaha pertanian melalui pelaksanaan program KRPL. Pelaksanaan program KRPL ditujukan untuk memenuhi kebutuhan pangan dan gizi keluarga sendiri, juga berpeluang meningkatkan penghasilan rumah tangga, apabila dirancang dan direncanakan dengan baik. Tidak semuanya berjalan dengan baik dalam pelaksanaan kegiatannya, permasalahan yang umum dihadapi adalah tingkat pengetahuan perempuan dalam memanfaatkan pekarangan rumah untuk pertanian masih rendah sehingga berdampak pada tingkat produktifitas tanaman yang dibudidayakan masih rendah, tingkat manajemen administrasi kelompok serta manajemen organisasi masih sangat lemah yang mengakibatkan kinerja dan tingkat kerjasama dari masing-masing.

\section{METODE PENELITIAN}

Penelitian ini dilakukan melalui metode pendekatan penelitian kualitatif yang bersifat deskriptif. Pendekatan penelitian kualitatif yang sesuai yaitu pendekatan fenomenologi, karena pendekatan fenomenologi berhubungan dengan pemahaman tentang bagaimana keseharian di kehidupan sehari-hari. Pendekatan fenomenologi yang digunakan peneliti bertujuan untuk menginterprestasikan gambaran tentang kebutuhan peserta terkait kebutuhan pendalaman materi serta penguasaan. Penelitian ini dilakukan di Kota Malang dengan jumlah informan sebanyak 36 orang dan waktu pelaksanaan penelitian pada bulan Januari s.d Maret 2018. Informan penelitian ditetapkan secara snowball sampling yaitu teknik penentuan responden dengan mengikuti informasi-informasi dari informan sebelumnya. Jenis data yang dikumpulkan dalam kegiatan penelitian yang dilaksanakan yaitu terdiri dari data primer dan data sekunder. Teknik pengumpulan data yang digunakan dalam penelitian ini adalah; observasi, wawancara, dan dokumentasi. Validitas yang digunakan meliputi trianggulasi. Adapun analisis data menggunakan model analisi Harvard dan analisis Longwe. 


\section{HASIL DAN PEMBAHASAN}

\section{Analisis Gender Model Harvard}

Profil aktifitas pada program pengembangan kawasan rumah pangan lestari diperoleh dari proses focus grup discussion dengan 36 informan dari Kota Malang. Aktifitas yang dimaksud adalah mencakup kegiatan produksi baik on farm maupun off farm dalam kegiatan program KRPL. Aktifitas produksi on farm mencakup usahatani dari pemilihan benih yang akan ditanam sampai dengan panen sedangkan produksi off farm meliputi pengolahan pasca panen, pemasaran hingga penggelolaan keuangan. Berikut akan disajikan profil aktifitas produksi pada Tabel 1 .

Tabel 1. Profil Aktifitas dalam Program KRPL

\begin{tabular}{|c|c|c|c|}
\hline \multirow[t]{2}{*}{ No } & \multirow[t]{2}{*}{ Aktifitas Usahatani } & \multicolumn{2}{|c|}{ Jumlah Informan } \\
\hline & & Laki-laki & Perempuan \\
\hline A & On Farm & & \\
\hline 1 & $\begin{array}{l}\text { Pemilihan benih yang akan } \\
\text { ditanam }\end{array}$ & 4 & 32 \\
\hline 2 & Menyemai benih & 6 & 30 \\
\hline 3 & Perawatan bibit & 2 & 34 \\
\hline 4 & Pencangkulan tanam & 36 & 0 \\
\hline 5 & Pembuatan vertikultur & 36 & 0 \\
\hline 6 & $\begin{array}{l}\text { Pemindahan bibit ke tanah atau } \\
\text { pot }\end{array}$ & 18 & 18 \\
\hline 7 & Penanaman & 0 & 36 \\
\hline 8 & Penyiraman tanaman & 11 & 25 \\
\hline 9 & Penyiangan & 7 & 29 \\
\hline 10 & Pemberian pupuk & 12 & 24 \\
\hline 11 & Pemberantasan hama & 18 & 18 \\
\hline 12 & Panen & 9 & 27 \\
\hline $\mathrm{B}$ & Off Farm & & \\
\hline 1 & Pengolahan tanaman pasca panen & 2 & 34 \\
\hline 2 & $\begin{array}{l}\text { Pemasaran (jika diperjual } \\
\text { belikan) }\end{array}$ & 6 & 30 \\
\hline 3 & Mencari nafkah diluar rumah & 22 & 14 \\
\hline
\end{tabular}

Tabel diatas menyajikan profil kegiatan produksi yaitu mulai dari pemilihan benih sampai dengan aktifitas pasca panen yang lebih dominan dilakukan oleh perempuan. Pelaksanaan program KRPL mampu menjadikan partisipasi perempuan menjadi dominan dalam kegiatan usahatani dikarenakan kegiatan ini difokuskan kepada perempuan dalam rumah tangga. Sedangkan laki-laki selaku kepala rumah tangga cenderung bekerja mencari nafkah diluar rumah.

Penelitian yang secara partisipatori melibatkan user perempuan agar teknologi ini responsif terhadap kebutuhan mereka termasuk kebutuhan peran gendernya dapat dikatakan belum berkembang. Beberapa penelitian menunjukan bahwa bila teknologi baru diperkenalkan ternayata teknologi itu tidak ramah pada perempuan. Dalam banyak kasus penelitian analisis gender belum banyak diaplikasikan dalam ranah pembangunan teknologi pertanian. Akibatnya aktifitas produksi ini dominan dilakukan oleh laki-laki pada aktivitas pencangkulan serta pembuatan vertikultur dan pemindahan benih ke tanah Jurnal Penyuluhan Pembangunan 1 (1) 2019 15-25 | 18 
atau pot. Ini dikarenakan aktifitas tersebut cenderung membutuhkan tenaga yang cukup besar dan tentunya bisa dilakukan oleh laki-laki. Hal ini seperti yang diungkapkan oleh TM (38 tahun) sebagai berikut:

"Hampir semuanya ya saya yang ngerjakan. Orang cuma nanam sama menyiram. Tapi ya kendalanya pas diawal waktu harus mengolah tanah terus buat bambu-bambu susun ya bapaknya yang mengerjakan" (TM 38 tahun).

Ini merupakan salah satu kendala yang dialami hampir oleh semua perempuan atau ibu rumahtangga. Pelaksanaan program KRPL secara umum diperuntukan kepada para perempuan untuk memaksimalkan penggunaan lahan pekarangan. Akan tetapi karena penerapan program KRPL salah satunya dengan menggunakan media vertikultur sehingga peran laki-laki masih diperlukan disini. Berbeda dengan yang dialami oleh TK (60 tahun) yang mengungkapkan bahwa:

"Saya hanya bisa menanam di plastik-plastik... Lha saya sudah ga kuat kalo mengerjakan dilahan. Jadi ya gak kaya orang lain. Ya sebisanya saja yang bisa saya kerjakan" (TK 60 tahun).

Pelaksanaan program KRPL ini untuk kegiatan produksi baik on farm maupun off farm tidak ditentukan secara seragam oleh Dinas Pertanian dan Ketahanan Pangan Kota Malang. Mulai dari pemilihan bibit yang akan dibudidayakan disesuaikan dengan kebutuhhan masing-masing rumahtangga. Terutama untuk sayur-sayuran seperti tomat, cabai, bayam dan lain sebagainya. Untuk rumah tangga yang memiliki lahan lebih luas sebagian juga membudidayakan buah-buahan seperti mangga dan klengkeng. Hasil panen dari pekarangan mayoritas warga masih digunakan untuk konsumsi keluarga. Ini merupakan salah satu upaya untuk menekan pengeluaran rumahtangga. Meskipun tidak terlalu signifikan apabila diterapkan secara nasional tidak menutup kemungkinan impor bahan pangan bisa ditekan.

Selanjutnya untuk aktifitas reproduksi yaitu berkaitan dengan urusan rumahtangga mulai dari mencuci, membersihkan rumah, mengatur menu yang akan dimasak, merawat anak sampai dengan dengan pencari nafkah serta pengelolaan keluarga. Berikut disajikan Tabel 2 profil aktifitas reproduksi yaitu:

Tabel 2. Profil Aktifitas Reproduksi

\begin{tabular}{clcc}
\hline No & \multicolumn{1}{c}{ Aktifitas Reproduksi } & \multicolumn{2}{c}{ Jumlah Informan } \\
\cline { 3 - 4 } & & Laki-laki & Perempuan \\
\hline 1 & $\begin{array}{l}\text { Mengatur menu makanan dan } \\
\text { memasak }\end{array}$ & 9 & 27 \\
2 & $\begin{array}{l}\text { Pengelolaan keuangan keluarga } \\
\text { Peny }\end{array}$ & 5 & 31 \\
\hline
\end{tabular}

Tabel diatas menyajikan profil aktifitas reproduksi yaitu mengatur menu dan memasak serta mengelola keuangan keluarga. Untuk kegiatan pengaturan menu dan memasak merupakan utama dari seorang perempuan dalam rumahtangga. Dari hasil observasi dilokasi diperoleh bahwa keputusan untuk pemilihan menu sepenuhnya diserahkan pada perempuan. Seperti informasi yang disampaikan oleh YT (55 tahun) sebagai berikut:

"untuk urusan masak-masak sama menu ya pasti ibu-ibu yang menentukan. Terkadang anak atau bapaknya yang minta dimasakan menu khusus".

Selanjutnya adalah kegiatan reproduksi dalam mencari nafkah terutama diluar rumah yang dominan dilakukan oleh laki-laki selaku kepala rumahtangga. Berdasarkan hasil FGD dilapangan, pada kegiatan ini laki-laki dominan bekerja diluar rumah 
sementara perempuan sebagian besar tidak bekerja diluar rumah. Berikut data pembagian waktu kerja dalam rumahtangga disajikan pada Tabel 3.

Tabel 3. Pembagian Waktu Kerja dalam Rumahtangga

\begin{tabular}{clcc}
\hline No & \multicolumn{1}{c}{ Jenis } & Laki-laki & Perempuan \\
\hline 1 & Jam kerja (dalam satu hari) & $8-10$ jam & $3-5$ jam \\
2 & Jam kerja (dalam satu minggu) & $56-70$ jam & $21-35$ jam \\
3 & Jam kerja (dalam satu bulan) & 160 jam & 60 jam \\
4 & Hari kerja (dalam satu bulan) & $21 \mathrm{HK}$ & $12 \mathrm{HK}$ \\
\hline
\end{tabular}

Melihat data diatas diketahui bahwa perempuan hanya bekerja dalam sehari ratarata adalah empat jam sedangkan untuk laki-laki adalah delapan sampai sepuluh jam. Sedangkan jam kerja dalam satu minggunya untuk perempuan rata-rata adalah 26 jam dan laki-laki sebanyak lima puluh enam sampai dengan tujuh puluh jam sehingga jika dihitung dalam satu bulan maka jam kerja untuk perempuan rata-rata adalah enam puluh jam dan laki-laki adalah seratus enam puluh jam. Kemudian pembagian hari kerja untuk perempuan adalah 12 hari kerja dan laki-laki adalah dua puluh satu hari kerja. Sejalan dengan hal tersebut waktu yang digunakan untuk mencari nafkah oleh laki-laki jauh lebih banyak karena banyak juga kepala keluarga yang terpaksa bekerja. Selain itu berdasarkan penelitian dilapang diketahui bahwa perempuan membantu menambah penghasilan dengan cara menekan pengeluaran belanja sehari-hari berdasarkan jumlah dan biaya isajikan pada Tabel 4 sebagai berikut:

Tabel 4. Perhitungan Belanja Kebutuhan Pangan dalam Rumah Tangga Berdasarkan Jumlah dan Biaya

\begin{tabular}{cccccc}
\hline No & Komoditi & $\begin{array}{c}\text { Biaya Belanja } \\
\text { Minimal Per } \\
\text { Hari }\end{array}$ & $\begin{array}{c}\text { Biaya Belanja } \\
\text { Selama Satu } \\
\text { Bulan }\end{array}$ & $\begin{array}{c}\text { Jumlah } \\
\text { Per Hari } \\
(\mathrm{Kg})\end{array}$ & $\begin{array}{c}\text { Jumlah } \\
\text { Per } \\
\text { Bulan } \\
(\mathrm{Kg})\end{array}$ \\
\hline $1 \quad \begin{array}{l}\text { Sayuran seperti } \\
\text { bayam, wortel, } \\
\text { bunga kol, buncis } \\
\text { Lauk pauk seperti } \\
\text { tempe, tahu, ikan, } \\
\text { ayam pokok }\end{array}$ & 10.000 & 300.000 & 0,5 & 15 \\
$\begin{array}{l}\text { Bahan } \\
\text { seperti beras }\end{array}$ & 12.000 & 360.000 & 1 & 30 \\
\hline \multicolumn{1}{c}{ Total } & 47.000 & 1.410 .000 & 2,5 & 75 \\
\hline
\end{tabular}

Berdasarkan tabel diatas diketahui bahwa besarnya biaya yang dikeluarkan sehari untuk bahan pangan rumah tangga adalah sebesar Rp. 47.000,- dan dalam satu satu bulan besarnya biaya adalah Rp. 1.410.000,- sedangkan untuk jumlah komoditas yang diperlukan keluarga dalam sehari adalah sebanyak $2,5 \mathrm{~kg}$ sehingga dalam sebulan yang dibutuhkan yang dibutuhkan adalah sebanyak 75 kilogram. Jika dalam sebuah rumahtangga mampu memanfaatkan pekarangan dengan menanam komoditas kebutuhan pangan meskipun tidak secara keseluruhan terpenuhi, paling tidak penekanan pengeluaran dapat dilakukan. Demikian pula jika masing-masing rumahtangga jika telah dapat menyediakan secara mandiri kebutuhan pangannya maka tidak menutup kemungkinan bahan pangan dapat ditekan. Inilah ujung tombak program pengembangan kawasan rumah pangan lestari sebagai upaya pemberdayaan perempuan melalui pengembangan Jurnal Penyuluhan Pembangunan 1 (1) 2019 15-25 | 20 
kawasan rumah pangan lestari untuk pemenuhan kebutuhan pangan rumahtangga. Pada bagian ini terdapat sub ordinasi perempuan dalam sektor pertanian karena perempuan dominan pada kegiatan reproduksi.

Dapat dikatakan bahwa perempuan adalah makhluk multi tasking dimana selain dominan menyelesaikan urusan rumahtangga, perempuan juga cukup berperan dalam kegiatan mencari nafkah sehingga terdapat kecenderungan perempuan mengalami beban kerja karena selain dominan melakukan kegiatan reproduksi mereka juga melakukan kegiatan produksi baik on farm dan off farm seperti yang disampaikan dibagian sebelumnya.

Aktifitas sosial kemasyarakatn mencakup kegiatan sosialisasi dan penyuluhan, kegiatan pertemuan program pengembangan KRPL, serta bekerja diluar rumah dalam sehari. Berikut disajikan pada Tabel 5 profil aktifitas sosial kemasyarakatan yaitu:

Tabel 5. Profil Aktifitas Sosial Kemasyarakatan

\begin{tabular}{cllcc}
\hline No & \multicolumn{2}{c}{ Aktifitas Sosial Kemasyarakatn } & \multicolumn{2}{c}{ Jumlah Informan } \\
& \multicolumn{2}{c}{ Laki-laki } & Perempuan \\
\hline 1 & Kegiatan sosialisasi dan penyuluhan & 5 & 31 \\
& KRPL & & 9 & 27 \\
2 & Kegiatan pertemuan & & 25 & 11 \\
3 & Kegiatan gotong royong atau bersih desa & & \\
\hline
\end{tabular}

Tabel diatas menyajikan profil aktifitas sosial kemasyarakatan yang menunjukan bahwa antara laki-laki dan perempuan keikutsertaanya seimbang. Seperti pernyataan yang disampaikan oleh KI (45 tahun) sebagai berikut:

"Kalau kegiatan penyuluhan dan pertemuan ya pasti ibu-ibunya yang ikut. Kadang setelah acara kegiatan PKK. Kalau acara kerja bakti ya bapak-bapaknya yang ikut. Ibuibu biasanya berperan untuk menyapu, membersihkan sampah, dan menyiapkan konsumsi”.

Untuk kegiatan penyuluhan dan pertemuan terkait program pengembangan KRPL memang dominan dilakukan oleh perempuan karena memang program tersebut diperuntukan kepada para perempuan dalam rumahtangga. Kemudian untuk kegiatan gotong royong dominan dilakukan oleh laki-laki karena merupakan kepala rumah tangga dan sangat dibutuhkan tenaga laki-laki, akan tetapi tidak menutup kemungkinan juga diikutsertakan perempuan dalam kegiatan gotong royong juga diperhitungkan.

1. Akses dan Kontrol Terhadap Sumberdaya

Pada lokasi penelitian terdapat dua sumberdaya yaitu sumberdaya fisik dan sumberdaya budaya. Sumberdaya fisik untuk program pengembangan KRPL mencakup air, tanah. Sumberdaya budaya mencakup informasi budidaya. Masuknya program pengembangan kawasan rumah pangan lestari memberikan masukan berupa pemanfaatan lahan yang terbatas menjadi tak terbatas karena menggunakan teknologi vertikultur. Semula dengan lahan yang sempit, para perempuan yang tidak bekerja diluar rumah dianggap belum bisa memberikan kontribusi terhadap keuangan keluarga yang sebelumnya hanya dibebankan kepada kepala keluarga. Namun dengan adanya program pengembangan kawasan rumah pangan lestari yang mengoptimalkan lahan sempit menjadikan peran perempuan menjadi lebih tinggi.

Berdasarkan hasil FGD dilokasi terdapat $69,44 \%$ atau 25 informan yang menyatakan bahwa akses pada sumberdaya lebih banyak dilakukan oleh perempuan sedangkan untuk kontrol dilakukan secara berimbang antara laki-laki dan perempuan dalam rumahtangga 
baik fisik maupun budaya. Hal ini dapat diartikan bahwa tidak ada intervensi dari pihak laki-laki selaku kepala rumahtangga. Selain itu dalam kegiatan program pengembangan kawasan rumah pangan lestari laki-laki tidak banyak dilibatkan karena memang dikhususkan untuk meningkatkan peran dan keberdayaan perempuan ditingkat rumahtangga.

2. Akses dan Kontrol Terhadap Manfaat

Manfaat yang dapat diambil dari lokasi penelitian ada dua yaitu manfaat praktis mencakup hasil panen dan penghasilan yang diperoleh serta kepemilikan aset pribadi kemudian manfaat strategis mencakup bertambahnya wawasan program pengembangan KRPL khususnya optimalisasi lahan dan aktualisasi diri. Berikut disajikan akses dan kontrol terhadap manfaat oleh laki-laki dan perempuan. Hasil ini diperoleh dari proses FGD yang dilakukan pada 36 informan yang 77,78\% atau sebanyak 28 informan menyatakan bahwa akses terhadap manfaat dari kegiatan program pengembangan KRPL dilakukan oleh perempuan.

Perempuan telah berperan aktif dalam kegiatan program pengembangan kawasan rumah pangan lestari mulai dari pemilihan bibit sampai dengan panen. Dengan begitu maka hasil yang diperoleh menjadi kewenangannya. Demikain pula dengan wawasan serta aktualisasi diri yang dicapai oleh perempuan yang bersifat mutlak dan tidak ada campur tangan dari pihak laki-laki.

\section{Faktor-faktor yang berpengaruh terhadap Akses dan Kontrol}

Mempertimbangkan akses yang dimiliki oleh laki-laki dan perempuan terhadap sumberdaya produktif serta kontrol apa yang mereka punyai dan siapa yang memperoleh keuntungan dari penggunaan sumberdaya tersebut. Akses adalah suatu kesempatan untuk melakukan sesuatu sedangkan kontrol adalah kemampuan untuk menguasai dan menentukan berbagai hal termasuk menutup atau membuka akses seseorang terhadap keterlibatannya dalam pembangunan yang pada akhirnya apakah akan membawa pada dampak, kesempatan atau justru hambatan. Menganalisis faktor-faktor dan kecenderungan yang menentukan pembagian kerja berdasarkan gender, hubungan gender serta akses dan kontrol.

Faktor-faktor yang berpengaruh terhadap akses kontrol yang pertama adalah kondisi demografis yang dominan perempuan. Kondisi ini membawa pada dampak upaya peningkatan aktualisasi kaum perempuan melalui program pengembangan kawasan rumah pangan lestari yang sejalan dengan kemauan pemerintah untuk mengikutsertakan perempuan sebagai subjek pembangunan nasional. Program pengembangan KRPL yang sengaja dikemas khusus untuk perempuan juga mendapat apresiasi dari pemerintah setempat. Sehingga dengan demikian peran serta perempuan dapat diperhitungkan sebagai upaya optimalisasi lahan pekarangan rumah mengingat budaya bahwa perempuan lebih baik bekerja dilingkup domestik rumahtangga menjadikan kesempatan positif bagi mereka. Meskipun ada beberapa program pengembangan KRPL yang cenderung sulit dilakukan oleh perempuan seperti mencangkul, pemindahan benih ke tanah atau pot serta pembuatan vertikultur.

\section{Analisis Gender Model Longwe}

Teknik analisis pemberdayaan Longwe digunakan dalam memahami isu perempuan dalam implementasi program pengembangan KRPL, mulai kebutuhan sampai dengan evaluasi program. Dalam teknik analisis pemberdayaan Longwe terdapat lima 
dimensi analisis yaitu akses, kontrol, partisipasi, kesejahteraan dan kesadaran kritis. Kelima dimensi tersebut saling berkaitan dan melengkapi di dalam pelaksanaan KRPL.

Hasil penelitian menunjukkan bahwa faktor akses dan kontrol tidak dapat dipisahkan. Keduanya adalah satu kesatuan yang saling melengkapi satu sama lain. Meskipun akses informasi dan keterampilan budidaya dalam kegiatan program pengembangan kawasan rumah pangan lestari sangat mudah diperoleh perempuan akan tetapi dalam penerapannya dominan dilakukan oleh laki-laki karena mayoritas kegiattan yang dilaksanakan dalam pertanian kurang ramah terhadap perempuan sehingga pengaplikasiannya sulit dilakukan. Dalam hal ini akses perempuan terhadap informasi sudah dikatakan sejajar dengan laki-laki sedangkan pada penerapannya masih belum. Akan tetapi selama kerjasama antara perempuan dan laki-laki dalam rumahtangga masih dikategorikan baik maka tujuan dari program pengembangan KRPL masih relatif dapat tercapai sehingga perlu adanya langkah atau tindakan lebih lanjut dari penentu kebijakan dalam hal ini Dinas Pertanian dan Ketahanan Pangan Kota Malang sebagai pelaku program pengembangan KRPL.

Perempuan sebagai bagian penting dari masyarakat menjadi unsur penting dalam pembangunan. Pembangunan pemberdayaan perempuan dilakukan untuk menunjang dan mempercepat tercapainya kualitas hidup dan mitra kesejajaran antara kaum perempuan dengan kaum laki-laki. Program pengembangan KRPL merupakan program pemerintah yang di dalamnya terdapat misi khusus untuk memberdayakan perempuan. Program pengembangan kawasan rumah pangan lestari merupakan sistem manajemen yang diterapkan dimasing-masing rumahtangga untuk mewujudkan kemandirian pangan ditingkat keluarga. Di dalam sistem manajemen terdapat aspek kontrol yang sangat penting bagi berjalannya sebuah kegiatan.

Berdasarkan pengamatan dilapangan diketahui bahwa upaya untuk memberdayakan perempuan dalam pengambilan keputusan penerapan program pengembangan KRPL baik kegiatan usahatani maupun non usahatani, kemudian pengelolaan keuangan keluarga dominan dilakukan oleh perempuan meskipun dalam aplikasinya pihak laki-laki masih terlibat sebagai bahan pertimbangan. Hal ini dibuktikan dengan adanya jawaban dari responden yang dominan lebih banyak dilakukan oleh perempuan. Sehingga dapat dikatakan bahwa dalam dua kegiatan tersebut perempuan sejajar peranannya dengan kaum laki-laki. Akan tetapi berbeda halnya dengan pengambilan keputusan dalam penggunaan teknologi dalam usahatani atau budidaya yang dominan dilakukan oleh laki-laki. Yaitu sebanyak 39 informan yang menjawab bahwa laki-laki yang lebih berperan dalam memberikan keputusan terkait penerapan teknologi. Hal ini dikarenakan perempuan tidak memiliki cukup kompetensi berkaitan dengan teknologi budidaya. Akbiatnya masih belum tercapai kesejajaran antara perempuan dengan laki-laki dalam kegiatan pemilihan teknologi budidaya.

Partisipasi merupakan indikator penting untuk melihat keberdayaan kaum perempuan. Partisipasi merupakan bentuk keikutsertaan individu dalam sebuah kegiatan atau program pengembangan kawasan rumah pangan lestari memang ditujukan kepada kaum perempuan sebagai upaya untuk membentuk rumahtangga yang mandiri pangan. Mengingat pangan merupakkan urusan perempuan dilingkup rumahtangga. Kebanyakan perempuan di Kota Malang tidak bekerja diluar rumah sehingga untuk penerapan program pengembangan KRPL sangat tepat untuk dilakukan.

Berdasarkan penelitian dilapang penerapan program pengembangan KRPL dilakukan secara bersama baik oleh perempuan maupun laki-laki dalam rumahtangga. Hal demikian terjadi karena adanya kerjasama yang baik antar kedua belah pihak meskipun 
untuk kegiatan penyuluhan rutin hanya dilakukan oleh kaum perempuan. Hal ini sesuai dengan pernyataan dari HN (49 tahun) bahwa:

"Kalau praktek budidaya ya bersama-sama bapaknya. Kalau saya ngerjakan sendiri ya gak bisa. Yang bisa ya bapaknya pakai cangkul trus naman-naman gitu biasanya saya. Perempuan tenaganya kan terbatas.

Akan tetapi kesejajaran belum terlihat pada kreatifitas dalam mengembangkan usahatani yang masih dominan dilakukan oleh laki-laki. Hal ini terjadi salah satunya dikarenakan perempuan sehari-hari hanya tinggal di dalam rumah atau lingkungan sekitar sedangkan para laki-laki yang mayoritas bekerja diluar rumah mempunyai kesempatan yang lebih banyak untuk memperoleh pengetahuan dan keterampilan untuk mengembangkan usahatani baik dibidang budidaya. Belum lagi keterbatasan tenaga kaum perempuan dibandingkan dengan laki-laki yang secara tidak langsung menyebabkan para perempuan sangat bergantung pada keberadaan laki-laki.

Sesuai dengan petunjuk pelaksanaan dan petunjuk teknis program pengembangan KRPL yang ditujukan kepada perempuan di Kota Malang adalah kegiatan pendidikan dan pelatihan program pengembangan KRPL telah diberikan. Upaya pemerintah untuk memberdayakan perempuan dapat dikatakan berjalan dengan baik. Terutama peran perempuan dalam pemenuhan kebutuhan pangan keluarga yang terdiri dari diversifikasi pangan dan pemanfaatan lahan pekarangan. Dengan demikian kesejajaran terhadap kaum laki-laki telah tercermin dari adanya program pengembangan kawasan rumah pangan lestari.

Kesadaran kritis adalah motivasi yang muncul dalam diri seseorang untuk menyadari penting tidaknya sebuah kegiatan atau sesuatu dalam hidup mereka. Program pengembangan kawasan rumah pangan lestari mengajak para perempuan untuk berdaya meskipun tidak dilakukan jauh dari lingkup domestik mereka yaitu keluarga. Sejak awal program diinisiasi oleh Dinas Pertanian dan Ketahanan Pangan Kota Malang apresiasi warga sangat baik. Ini menjadi modal penting bagi keberhasilan sebuah program pengembangan KRPL. Dengan adanya apresiasi yang baik maka dapat dilihat motivasi dalam diri kaum perempuan di Kota Malang relatif baik. Mayoritas dari mereka menyadari akan pentingnya keberadaan program pengembangan KRPL sebagai bentuk usaha untuk mencukupi kebutuhan sehari-hari khususnya pangan dengan mandiri. Lebih lanjut keikutsertaan dalam kegiatan-kegiatan seperti ini adalah cara terbaik untuk meningkatkan aktualisasi diri dengan bertambahnya pengetahuan dan keterampilan yang nantinya diharapkan akan memberikan manfaat untuk jangka panjang. Dengan demikian kesejajaran kaum perempuan terhadap laki-laki bisa direalisasi sebagai konsekuensi dari pembangunan sumberdaya manusia.

\section{KESIMPULAN}

Berdasarkan analisis Harvard diketahui bahwa profil aktifitas kaum perempuan pada program pengembangan KRPL dibandingan dengan laki-laki adalah lebih dominan. Akan tetapi pada sub kegiatan yang penting seperti penggunaan teknologi dan pengambilan keputusan terkait budidaya justru secara tidak langsung mayoritas dilakukan oleh laki-laki dalam rumahtangga. Sehingga secara tidak langsung pada aspek kegiatan yang vital justru perempuan dapat dikatakan bergantung kepada laki-laki. Jika hal seperti ini terus menerus dibenarkan dan membudaya, maka tujuan pemberdayaan perempuan dalam program pengembangan kawasan rumah pangan lestari tidak akan tercapai. Perempuan akan terus menerus menjadi bayang-bayang dalam pembangunan dibawah laki-laki. 
Pada analisis Longwe juga demikian memang sudah benar bahwa secara petunjuk pelaksanaan pengembangan kawasan rumah pangan lestari menjadikan perempuan sebagai sasaran program. Tetapi pada akhirnya perempuan tidak pernah menjadi sejajar dengan laki-laki dalam pembangunan.

\section{V.SARAN}

Dinas Pertanian dan Ketahanan Pangan Kota Malang sebagai perpanjangan tangan dari Kementerian Pertanian sudah seharusnya peka terhadap fenomena dilapangan, sehingga sebagai bahan yang memiliki tugas utama untuk merumuskan teknologi pertanian mampu memformulasikan sebuah teknologi pertanian yang ramah lingkungan.

\section{DAFTAR PUSTAKA}

Achmad Muthali'in. 2001. Bias Gender Dalam Pendidikan. Surakarta: Muhammadiyah University Press.

Ambar T. Sulistyani. (2004). Kemitraan Dan Model-Model Pemberdayaan. Yogyakarta: Gava Media.

Fahrudin Adi. (2012). Pemberdayaan Partisipasi Penguatan Kapasitas Masyarakat. Bandung: Humaniora.

Fitriana YD, Yayuk Yuliati, Sanggar Kanto, 2011. Pemberdayaan Perempuan Melalui Pemanfaatan Pekarangan dengan Sistem Pertanian Organik dalam Rangka Peningkatan Kesejahteraan Keluarga. Lokakarya Nasional Pengakuan Studi Wanita Sebagai Bidang Ilmu, Cetakan Pertama, Tahun 2011, ISBN : 978-602203-034-8.

Indriyati, dan Nugahani, 2010, "Pemberdayaan Perempuan Sebagai Strategi Penanggulangan Kemiskinan (Studi Tentang Program Pengentasan Kemiskinan di Kecamatan Cangkringan Kabupaten Sleman)," Laporan Penelitian Studi Kajian Wanita.

Moleong. (2005). Metodologi Penelitian Kualitatif. Bandung: PT. Remaja Rosda Karya.

Sugiyono. (2011). Metode Penelitian Kuantitatif, Kualitatif dan R\&D. Bandung: Alfabeta.

Winarni.F., 1994, Peran Partisipasi Masyarakat dalam Program Pengentasan Kemiskinan, Cakrawala Pendidikan, No.2, Th XIII, Juni. 